\title{
LÍNGUA PORTUGUESA E CONSTITUIÇÃO ESTRUTURAL
}

\author{
Priscila Ferreira de Alécio \\ Leandra Inês Seganfredo Santos²
}

A obra "Estrutura da Língua Portuguesa: Ediçâo Crítica" tem em seu bojo os processos de compreensăo da língua portuguesa, bem como as regras que circundam nela, sob ediçăo de Emílio Pagotto, Maria Cristina Silva e Manoel Mourivaldo Santiago Almeida. De início os organizadores expóem os pontos que foram mudados do livro Estrutura da Língua Portuguesa na versâo de Mattoso, para a versăo atual. Mudanças essas que decorreram, para melhor compreensăo do leitor, ou para atualizaçôes, tendo em vista o novo acordo ortográfico.

No que concerne às mudanças ocorridas na ediçáo crítica, na apresentaçăo, os editores dăo a base geral de quais as mudanças que o livro apresenta, se comparado com a ediçấo anterior. De início, denotam a importância da obra de Mattoso, Estrutura da Língua Portuguesa, antes dessa ediçấo. Segundo eles, a obra inicial pôde contribuir para a formaçâo na Linguística Teórica.

Na sequência, explanam alguns critérios adotados, sendo eles de cinco naturezas: macroestruturais, de diagramaçăo, textuais, normativas e de atualizaçăo de caracteres gráficos. Um dos aspectos interessantes da ediçăo crítica sâo as notas editorias, ao final de cada capítulo, para auxiliar o leitor na compreensấo.

Quanto aos aspectos macroestruturais, percebe-se duas mudanças em relaçăo a obra anterior, o acréscimo de títulos as seçôes, que contribuem para a organizaçăo no processo de leitura e as bibliografias que eram ausentes. Foram necessárias também algumas alteraçóes textuais, como a troca de uma palavra por outra, como no exemplo trazido na secçăo 6, na obra anterior, a frase é da seguinte forma: "Isso năo quer dizer que a gramática descritiva seja um bloco monopolítico", e passou a ser "Isso năo quer dizer que a gramática descritiva seja um bloco monolítico". Segundo os editores, o termo "monopolítico" nâo seria adequado ao contexto.

1 Graduada em Letras Língua Portuguesa/Língua Inglesa pela Universidade do Estado de Mato Grosso, atualmente participa do Projeto Diversidade e Variaçáo Linguística em Mato Grosso (DIVALIMT) e é Mestranda do Programa de Pós Graduaçăo em Letras (Strictu Senso) na área de Estudos Linguísticos com pesquisas concernentes à Sociolinguística e Perceptual Dialectology.

2 Possui graduaçâo em Pedagogia pela Universidade do Estado de Mato Grosso (1994), mestrado em Estudos de Linguagem pela Universidade Federal de Mato Grosso (2005), doutorado em Estudos Linguísticos (Linguística Aplicada) pela UNESP (Rio Preto) e Pós-doutorado em Linguística Aplicada e Estudos da Linguagem (PUCSP). É professora concursada na Universidade do Estado de Mato Grosso. 
Algumas alteraçôes sâo significativas também no que concerne ao cunho normativo, ou seja, realizaram-se devido a equívocos gramaticais, assim como os sinais de pontuaçấo, que configuram, na obra atual, maior consonância com as normas.

Alteraçôes nos caracteres gráficos, principalmente com relaçáo ao acordo ortográfico, sendo esta ediçáa atualizada de acordo com o vigente. No que concerne a formataçấo do texto, a ediçăo crítica coaduna com as normas, principalmente no que diz respeito às citaçôes diretas, até três linhas, o uso de aspas, acima de número, recuo no texto a ser transcrito. Os símbolos fonéticos também foram atualizados segundo o Alfabeto Fonético Internacional.

A seguir, fazem uma introduçâo à formaçáo da língua, para isso expóem as noçōes de gramática. No primeiro capítulo intitulado gramática e seu conceito é discorrido sobre o que é a gramática, de início pela descritiva ou sincrônica: "estudo do mecanismo pelo qual uma dada língua funciona num dado momento." Ao empregar este termo sem outro qualificativo, há o entendimento que é um estudo do momento atual. A normativa refere à arte de escrever e falar corretamente. Nos estudos Saussureanos houve a divisăo em sincronia e diacronia, que por sua vez, almejava transformar a gramática em uma disciplina independente.

No segundo capítulo, intitulado "Variabilidade e invariabilidade da língua" há a compreensáo que a língua varia de acordo com o contexto de forma que cria dialetos, assim como no próprio indivíduo, surgem, de acordo com as circunstâncias, uma variedade. Roman Jakobson afirma que o princípio das invariantes é que faz a criaçăo das normas linguísticas. Ainda nesse ponto, o autor discorre no que concerne à diferença, eminente, entre língua e fala, Ambas săo totalmente diferentes, sendo a escrita o modelo que a escola privilegia. Dessa forma, o aluno adentra na escola dominando a linguagem familiar que é diferente do processo de escrita.

No capítulo intitulado "a técnica da descriçăo linguística", há presença dos conceitos chaves de homonímia e polissemia, presentes nas línguas, em que a polissemia assume a possibilidade de uma forma possuir outros sentidos, já a homonímia, as mudanças decorrem também na organizaçâo sintática da frase.

A fim de que haja melhor compreensáo da constituiçâo da língua, o autor dividiu em duas partes em que a primeira trata dos processos fonológicos e a segunda da morfologia da língua. Nessa construçaáo está o capítulo “Sons vocais elementares e fonemas" que inicia com a discussăo do surgimento da fonologia em complemento com a fonética para que, de fato, os sons da língua fossem registrados. Nos princípios de Saussure houve a criaçăo dos fonemas. Para a distinçăo da fonêmica, ou seja, a fonologia, a transcriçấo das palavras, ocorre por intermédio de barras (//); já para a fonética ocorre entre colchetes ([]). A alofonia que é a alteraçăo do fone ocorre devido às variantes, e esta pode ocasionar na confusáo dos sentidos, no que se refere ao aprendizado de uma língua estrangeira, por exemplo. Para ilustrar, o autor trouxe o <th> que pode ser pronunciado por um brasileiro como /t/ ou /s/. Assim, a frase It is thin (é delgado) pode soar como It is Tin (é uma lata) it is sin (é um pecado). Por fim, Camara Junior ressalta que a classificaçăo articulatória pro- 
movida por Jakobson é atualmente a utilizada no ensino, e săo classificadas como labiais, labiodentais, dentais, alveolares, pré-palatais, médio palatais e velares.

As "vogais e as consoantes portuguesas" formam o quinto capítulo, que trata da importância do acento, intensidade, ou força expiratória, que associada ao tom da voz constitui a posiçâo para caracterizaçâo da sílaba. A harmonizaçâo vocálica é um procedimento que determina um sentido a palavra por meio de apenas uma vogal diferente. Duas palavras podem ser muito semelhantes na fala, porém possuem noçōes diferentes. As palavras 'comprido' e 'cumprido' possuem semelhanças, no entanto, uma refere-se a uma medida e a outra a execuçăo de algo, respectivamente.

O sexto capítulo trata das "estruturas da sílaba em Português" que aborda quando o reconhecimento da sílaba ocorre devido ao efeito sonoro, da força expiratória e do encadeamento articulatório das sílabas na produçâo vocal. O fenômeno da ligaçấo ocorre no processo da fala, em que tem-se um substantivo com o adjetivo e o verbo com o respetivo complemento. Um exemplo é a sentença 'falas hoje' que no ato de fala, /fa-la-zo-i/. Nesse caso, a consoante final liga-se a vogal sonora, de início da palavra seguinte.

A "acentuaçâo e o vocábulo fonológico" constituem o sétimo capítulo com foco na força expiratória, ou seja, o acento; este, por sua vez, depende da intensidade de emissăo para que tenha sentido. Constitui como demarcativo e distintivo em que culmina para o entendimento e diferenciaçăo de palavras, como no exemplo jaca, (uma fruta brasileira) e jacá (uma espécie de cesto).

Na segunda parte do livro há abordagens concernentes com a morfologia da língua, como é sua estrutura. $\mathrm{O}$ "vocábulo formal e a análise mórfica" constituem o oitavo capítulo. Ao contrário da fala, a apresentaçáo do vocábulo formal apresenta-se na escrita. As convençôes da escrita diferem-se da fala devido ao maior rigor e normativa que esta possui. A análise mórfica consiste no radical, que é a estrutura da palavra, aquela invariável, em consonância com as outras terminaçôes das palavras que delimitam gênero, número e grau. Uma amostra desse fato é o verbo 'falar', que na primeira pessoa do plural, 'falamos', foi acrescida a parte que nâo varia, o sufixo determinante -mos, que indica a pessoa e o número que está conjugado. Pode-se notar que essas terminaçōes mudam ao referir-se ao tempo futuro, assim, ocorre variaçăo na constituiçáo da palavra.

No nono capítulo, a "classificaçăo dos vocábulos formais", discorre sobre o critério morfossemântico, haja visto que os critérios mórfico e semânticos estăo ligados. Os vocábulos sâo tratados como nomes que sâo associados às coisas. Para que os vocábulos tenham ligaçăo, sâo necessários que possuam conectivos, e estes pertencem às classes menores. Os conectivos podem ser coordenativos ou subordinativos a depender das circunstâncias que sâo utilizados.

No décimo capítulo, trata sobre "o mecanismo de flexăo de língua portuguesa" que apresenta-se no português como objetos posteriores ao radical. Os adjetivos portugueses quando acionados alguns elementos postônicos, em especial o sufixo, transformam-se em grau do adjetivo, como o exemplo a palavra 'triste' que torna-se 'tristíssimo'. Os sufixos flexionam-se em gênero e número, o primeiro 
acondiciona-se na forma masculina e feminina e o segundo em singular e plural. A vogal temática que delimita de qual conjugaçáo pertence o verbo, se termina em -ar, primeira, -er segunda e -ir terceira.

O décimo primeiro capítulo aborda "o nome e suas flexôes", que discute como os substantivos e adjetivos caminham juntos. $\mathrm{O}$ adjetivo caracteriza, qualifica o substantivo. No que concerne à flexăo de gênero o autor trata da importância dessa discussăo tendo em vista que nem sempre um oposto a uma palavra é outro gênero. Há, por exemplo, casos de seres como 'cobra' que nâo tem uma palavra que a distingue como macho ou fêmea, e sim a caracterizaçâo da palavra 'cobra macho' e 'cobra fêmea'. Outra flexâo nominal que Câmara Junior trata é a de número, ou seja, ao inserir um sufixo que pluraliza, a palavra descreve uma situaçâo coletiva, com exceçâo dos substantivos coletivos que, por si só, delimitam um conjunto. Na maioria das palavras, basta adicionar o morfema /s/ para que esta pluralize-se.

A "significaçâo geral das noçôes gramaticais do verbo" constitui o décimo segundo capítulo. Nesse tópico o autor trata dos fatores que trazem o sentido para o verbo, nesse caso o pretérito e o presente para que tenha-se a noçăo de futuro. No que concerne as formas nominais tem-se o infinitivo, gerúndio e particípio sendo o primeiro a forma mais indefinida do verbo. Gerúndio é caracterizado como imperfeito, um processo que ainda năo foi concluído de modo que o particípio é concluso e perfeito, finalizado.

A "flexăo verbal portuguesa - o padrâo geral", é o que trata o décimo terceiro capítulo que discorre sobre a conjugaçâo que muda o verbo da fase do infinitivo para uma palavra que pode denotar o tempo e o número, de acordo com os sufixos que lhes sâo colocados. A tonicidade do verbo em português incide sobre a vogal temática. Há também a possibilidade da vogal temática ser nula, como no exemplo, 'cantar', quando conjugado no presente, em primeira pessoa do singular, a vogal temática -a deixa de existir, de modo que é substituída por -o, que é o sufixo denotativo para esse tempo verbal. $O$ autor expōe alguns quadros comparativos exemplificando onde a vogal temática é substituída e permanece.

O décimo terceiro capítulo aborda "os padrōes especiais dos verbos em português" ou seja, há, em sua maioria, verbos regulares que sâo conjugados de acordo com os tempos e modos verbais, no entanto, há também alguns verbos que nâo seguem essa regra, ditos irregulares. Săo pequenos grupos de verbos que seguem um padrâo năo comum, em relaçâo ao regulares. Faz mençáo também aos processos de nasalizaçăo presentes na língua portuguesa como a vogal 'm' por exemplo.

Por fim o último capítulo trata dos "sistemas de pronomes em português" que consiste na noçăo de pessoa, utilizado ao invés do emprego repetitivo de nomes e de substantivos próprios. O pronome comum utilizado atualmente é o 'você' que vem do pronome 'tu' segunda pessoa do plural. Os pronomes possessivos indicam posse de algo, bem como um identificador de pertença a alguém, exemplo ‘sua opiniăo'.

Nas últimas páginas dos livros, os organizadores fazem algumas notas para que o leitor possa situar-se no transcorrer da obra, além das referências bibliográficas 
que foram utilizadas. Dessa forma tem-se alguns esclarecimentos no que concerne a versăo inicial.

Assim o livro faz um percurso gramatical e fonológico de aspectos das línguas, náo somente da língua portuguesa, mas pauta-se em questōes que envolvem também outras línguas, informaçōes úteis para aqueles que almejam estudar um novo idioma. Essa obra tem uma base que pode ser utilizada nos cursos de Letras, haja visto o quâo esclarecedor e informativo é. Nessa perspectiva, é um manual que poderia ser adotado nas universidades que ofertem cursos de licenciatura.

\section{REFERÊNCIAS}

CAMARA JÚNIOR, Joāo Mattoso. Estrutura da Língua Portuguesa. Petrópolis, Rio de Janeiro: Vozes, 2019. 